\title{
Pengaruh spiritualitas dan persepsi dukungan organisasi terhadap keterikatan kerja anggota Satuan Reserse Polres Lamongan
}

\section{The effect of spirituality and perceived organizational support to employee engagement Members of the Lamongan Police Reserse}

\author{
Ari Bayuaji \\ Program Studi Magister Kajian Ilmu Kepolisian, Sekolah Pascasarjana, Universitas Airlangga \\ Surabaya, 60286, Jawa Timur, Indonesia \\ E-mail: ari.bayuaji@pasca.unair.ac.id
}

\begin{abstract}
Abstrak
Beban kerja satuan Reserse membutuhkan motivasi yang kuat bagi personelnya untuk melaksanakan pekerjaan dengan sepenuh hati. Dengan demikian beban kerja yang berat akan dilihat dalam perspektif yang lebih positif. Kecerdasan untuk melihat dari perspektif yang lebih positif terhadap beban kerja sangat dibutuhkan bagi satuan fungsi teknis Reserse dalam kaitannya untuk menjaga agar kinerja personel tetap baik disamping juga untuk menjaga personelnya untuk tetap loyal berada di bidang tugasnya dan tidak berpindah fungsi karena alasan beban dan resiko kerja. Data primer dalam penelitian ini didapat melalui penyebaran kuesioner kepada seluruh anggota Satreskrim Polres Lamongan dengan jumlah 60 orang. Kuesioner selain berisi tentang pernyataan yang sesuai dengan keadaan diri responden juga berisi pertanyaan terbuka yang harus dijawab responden secara jujur, untuk mendukung peneliti dalam melakukan pendalaman terhadap responden. Teknik analisis dalam penelitian ini menggunakan regresi linear berganda dengan alat analisis SPSS versi 24. Hasil pengujian secara statistik menunjukkan pengaruh yang positif dan signifikan antara variabel bebas (spiritualitas dan persepsi dukungan organisasi) terhadap variabel terikat (keterikatan kerja) baik secara parsial ataupun simultan (bersama-sama).
\end{abstract}

Kata kunci: beban; motivasi; spiritual; organisasi; kerja

\begin{abstract}
Detective unit workload requires strong motivation for its personnel to carry out the work wholeheartedly. Thus the heavy workload will be seen in a more positive perspective. The intelligence to see from a more positive perspective on workload is very much needed by the Detective technical function unit in relation to ensuring that the performance of personnel remains good as well as to keep their personnel loyal in the field of duty and not changing functions due to workload and risk reasons. Primary data in this study were obtained through the distribution of questionnaires to all members of the Lamongan Police Secretariat with a total of 60 people. The questionnaire in addition to containing statements in accordance with the state of the respondent's self also contained open questions that must be answered honestly by the respondent, to support researchers in conducting deepening of the respondent. The analysis technique in this study uses multiple linear regression with SPSS version 24. The statistical test results show a positive and significant effect between independent variables (spirituality and perceived organizational support) on the dependent variable (work engagement) either partially or simultaneously (together-same).
\end{abstract}

Keywords: expense; motivation; spiritual; organization; work

\section{Pendahuluan}

Anggota reserse yang bekerja di lapangan berhadapan langsung dengan masarakat memiliki derajat stress yang lebih tinggi. Hal tersebut diakibatkan karena beban kerja yang terlalu banyak (over load) dan karena keahliannya di lapangan jarang dilakukan rotasi atau pergantian. Mereka menangani langsung masalah sosial dan kejahatan di masyarakat (Daryanto 2005). Anggota reserse yang terjun langsung di lapangan tidak dalam waktu yang singkat untuk merintis kerjanya dalam mengungkap kejahatan. Beban kerja yang terlalu banyak (over load) dan tekanan kerja dapat memicu tingginya tingkat stres pada anggota reserse (Morash et al 2011; Tucker 2015) Petugas polisi memiliki tingkat stres kerja yang tinggi mengalami masalah psikologis dan fisik yang tinggi. Pada umumnya mereka mengalami gangguan kesehatan, sering absen dari pekerjaan, mengalami kebosanan terhadap pekerjaan dan tidak puas dengan pekerjaannya sehingga berakibat pada perilaku menyimpang anggota 
atau bahkan pelanggaran disiplin dan tindak pidana. Data pengaduan masyarakat yang diterima Bidpropam Polda Jatim terkait dengan pelanggaran dan penyimpangan anggota Polri di wilayah hukum Polda Jawa Timur tahun 2016 dan 2017 diketahui bahwa paling banyak adalah terkait dengan kesalahan prosedur dan ketidakprofesionalan anggota dalam menangani perkara masyarakat. Selain itu dari data juga diketahui bahwa permasalahan yang paling banyak disidangkan adalah terkait disiplin yakni sebanyak 704 kasus. Serta KEPP (Komisi Kode Etik Polri) sebanyak 296 kasus.

Beban kerja satuan Reserse mebutuhkan motivasi yang kuat bagi personelnya untuk melaksanakan pekerjaan dengan sepenuh hati. Dengan demikian beban kerja yang berat akan dilihat dalam perspektif yang lebih positif. Kecerdasan untuk melihat dari perspektif yang lebih positif terhadap beban kerja sangat dibutuhkan bagi satuan fungsi teknis Reserse dalam kaitannya untuk menjaga agar kinerja personel tetap baik di samping juga untuk menjaga personelnya untuk tetap loyal berada di bidang tugasnya dan tidak berpindah fungsi karena alasan beban dan resiko kerja. Motivasi yang kuat akan menghasilkan keterikatan pada pekerjaan (employee engagement) dan hasilnya pekerjaan dapat dilaksanakan dengan baik.

Dalam penelitian ini penulis memberikan analisis mengenai variabel apa saja yang mempengaruhi keterikatan kerja (employee engagement) anggota Satuan Reserse Polres Lamongan. Dari dugaan sementara penulis, keterikatan kerja (employee engagement) dipengaruhi oleh spiritualitas (spiritualitas) dan persepsi dukungan organisasi (perceived organizational support) dari anggota Satuan Reserse Polres Lamongan.

Hal ini didasarkan pada penelitian oleh Ursitti (2011) yang menyebutkan bahwa terdapat temuan penelitian yang menyatakan bahwa petugas polisi yang secara teratur beribadah atau bermeditasi menunjukkan performa pekerjaan yang lebih baik. Penelitian tentang spiritualitas ini telah banyak dikaji oleh berbagai peneliti seperti Lazar (2009), Morales (2015), Srivastava et al (2014), Vivek \& Amrith (2017), dan Zobal (2014). Dalam penelitian tersebut dapat disimpulkan bahwa spiritualitas dapat dijadikan bagian integral dalam tugas-tugas kepolisian. Selain Spiritualitas (spiritualitas) ada varabel lain yang akan berpengaruh terhadap keterikatan kerja (employee engagement) anggota Satuan Reserse Polres Lamongan. Kirana (2015) menyatakan bahwa terdapat beberapa faktor yang mempengaruhi terbentuknya keterikatan kerja (employee engagement) antara lain dukungan organisasi (perceived organizational support). Faktor dukungan organisasi muncul dari eksternal pribadi individu, sehingga masing-masing individu akan mempersepsikan dukungan yang diberikan oleh organisasi terhadap individu dalam melaksanakan tugasnya.

Jadi tugas pokok kepolisian yang dilakukan oleh anggota Satuan Reserse Polres Lamongan yang penuh resiko dan tanpa mengenal waktu serta harus siap dalam situasi dan kondisi apapun anggota Satuan Reserse Polres Lamongan harus dapat mengemban tugasnya dengan baik. Tuntutan tugas tidak hanya berasal dari internal organisasi namun juga dari masyarakat yang membutuhkan keberadaan anggota Polri setiap saat. Tentu saja dalam melaksanakan tugas tersebut tersebut dibutuhkan keterikatan kerja anggota Satuan Reserse Polres Lamongan. Peneliti berpendapat bahwa dengan adanya Spiritualitas (spiritualitas) yang melekat pada anggota Reserse serta adanya Persepsi Dukungan Organisasi (perceived organizatinal support) akan berpengaruh terhadap keterikatan kerja (employee engagement) anggota Reserse khususnya anggota Satuan Reserse Polres Lamongan.

Pengukuran spiritualitas yang akan digunakan berdasarkan dimensi dimensi: innerness or Inner Resources, purpose and meaning in life, transcendence, dan unifying interconnectedness. Innerness atau inner Resources: Howden mendefinisikan innernes sebagai perjuangan atau pencarian akan keutuhan, identitas dan rasa pemberdayaan diri (Ursitti 2011). Purpose and meaning in life: individu memiliki perasaan yang sama dalam mencari maksud dan makna yang lebih mendalam dalam kehidupannya dan juga terhadap pekerjaan yang dilakukannya. Rasa tujuan (sense of purpose) atas apa yang dikerjakan dapat muncul dari kualitas intrinsik dari pekerjaan yang sedang dilakukannya, maupun tujuan yang akan dicapai atau dicari dari suatu pekerjaan. Transcendence: ketika individu mengalami stress yang tinggi atau terpapar pada situasi yang traumatis, kadang muncul suatu pertanyaan "Di manakah Tuhan selama ini?", hal tersebut mencerminkan hasrat akan transendensi di 
tengah situasi yang menekan (Ursitti 2011). Individu yang bekerja dan menjalani situasi demikian dapat mengembangkan rasa akan makna dan dan tujuan hidup yang menimbulkan pertumbuhan spiritualitas dalam dirinya (Ursitti 2011). Unifying interconnectedness: tempat kerja adalah sebuah komunitas. Perasaan menjadi bagian dari suatu komunitas adalah element yang esensial dari perkembangan spiritualitas individu (Ursitti 2011). Memahami spiritualitas di tempat kerja adalah menyadari bahwa orang memiliki kehidupan di dalam dirinya maupun di luar dirinya. Spiritualitas di tempat kerja muncul diantaranya dikarenakan individu ingin merasa terlibat dalam pekerjaan yang penting dan merasa terhubung dengan orang di lingkungannya satu sama lain. Ketika seseorang bekerja, hubungan dengan orang di sekitarnya merepresentasikan bagian dari kehidupannya seharihari. (Ursitti 2011).

Dimensi persepsi dukungan organisasi (perceived organizational support) menurut Rhoades \& Eisenberger (2002) adalah sebaga berikut: Pertama, fairness, yaitu keadilan dalam pelaksanaan tugas dan pembagiannya di antara karyawan dalam suatu organisasi. Rhoades \& Eisenberger (2002) mengemukakan bahwa berulangkali contoh keadilan dalam keputusan mengenai pembagian pekerjaan mempunyai efek kumulatif yang kuat terhadap persepsi dukungan organisasi (perceived organizational support) dengan menunjukkan kepedulian terhadap kesejahteraan karyawan. Kedua, supervisor support, adalah tindakan kebijakan dan keputusan seorang atasan dalam suatu organisasi. Atasan pada organisasi juga mempunyai wewenang untuk mengarahkan dan mengevaluasi performa dan kinerja bawahannya. Karyawan membentuk persepsi secara umum mengenai penilaian organisasi, mereka mengembangkan pandangan umum yang menyangkut sejauh mana supervisor/atasan menilai kontribusi mereka dan peduli tentang kesejahteraan mereka, yaitu terkait dukungan atasan yang dirasakan oleh anggotanya (Rhoades \& Eisenberger 2002).

Organizational rewards and job conditions, yakni penghargaan organisasi dan kondisi pekerjaan yang mencakup persepsi karyawan yang berkaitan dengan penghargaan dari organisasi terhadap kondisi pekerjaan dan sumber daya di dalam suatu organisasi. Rhoades \& Eisenberger (2002) menyampaikan bahwa praktik sumber daya manusia oleh suatu organisasi harus menunjukkan pengakuan terhadap kontribusi karyawan terhadap organisasi, misalnya seperti pengakuan, pembayaran, promosi, keamanan kerja, otonomi, stressor peran, dan pelatihan. Pengakuan, pembayaran, dan promosi, menurut teori dukungan organisasi berfungsi untuk mengkomunikasikan penilaian positif dari kontribusi karyawan sehingga akan menimbulkan persepsi dukungan organisasi (perceived organizational ssupport) terhadap karyawan tersebut (Rhoades \& Eisenberger 2002).

Dimensi Keterikatan Kerja (employee engagement) menurut Schaufeli (2013) ada tiga yaitu: pertama, giat (vigor), semangat dikarakteristikkan dengan tingginya level energi dan ketahanan mental saat bekerja, kemauan untuk memberi upaya lebih dalam bekerja dan ketekunan dalam menghadap kesulitan. Kedua, dedikasi (dedication), dedikasi dikarakteristikkan dengan adanya perasaan berarti, antusiasme, inspirasi, kebanggaan dan tantangan. Ketiga, keasikan (absorption), keasikan dikarakteristikkan dengan konsentrasi penuh dan kesenangan dalam menjalani pekerjaan, di mana tanpa terasa waktu berjalan cepat dan individu sulit melepas diri dari pekerjaannya.

\section{Metode Penelitian}

Pendekatan yang digunakan peneliti dalam melakukan penelitian ini adalah dengan menggunakan pendekatan kuantitatif. Penelitian dengan pendekatan kuantitatif merupakan penelitian eksplanatif (penelitian menjelaskan). Bungin (2011) menjelaskan bahwa penelitian eksplanatif adalah penelitian yang menggunakan data yang sama, di mana peneliti menjelaskan hubungan kausal antara variabelvariabel melalui pengujian hipotesis.

Metode penelitian yang digunakan peneliti dalam penelitian ini adalah metode penelitian survei. Sementara itu populasi dalam penelitian ini adalah seluruh anggota Satuan Reserse Polres Lamongan. Adapun jumlah anggota satuan reserse Polres Lamongan sebanyak 60 orang. Karena jumlah populasinya tidak lebih besar dari 100 orang responden, maka peneliti mengambil $100 \%$ jumlah populasi yaitu anggota Satuan Reskrim Polres Lamongan sebanyak 60 responden. Teknik sampling 
jenuh yaitu teknik penentuan sampel dengan cara semua anggota yang ada dalam populasi digunakan sebagai sampel (Sugiyono 2010). Adapun penelitian ini yang menjadi variable bebas (X) adalah spiritualitas (Spirituality/X1) dan persepsi dukungan organisasi (perceived organizational support/X2). Variabel tidak bebas atau terikat atau variabel terpengaruh (dependent variable) adalah variabel akibat yang diperkirakan terjadi kemudian. Adapun yang menjadi variabel tidak bebas dalam penelitian ini adalah keterikatan kerja (employee engagement) anggota Satuan Reserse Polres Lamongan (Y).

Uji validitas, menurut Bungin (2011) validitas adalah seberapa jauh alat dapat mengukur hal atau subjek yang ingin diukur. Adapun uji validitas dirumuskan dengan korelasi Product Moment sebagai berikut:

$$
r_{x y}=\frac{n\left(\sum X Y\right)-\left(\sum X\right)\left(\sum Y\right)}{\sqrt{\left(\sum X^{2}\right)-\left(\sum X\right)^{2} \operatorname{In}\left(\sum Y^{2}-\left(\sum Y\right)^{2}\right.}}
$$

Di mana $r_{x y}=$ koefisien korelasi suatu butir/item

$\mathrm{N} \quad=$ jumlah subjek

$\mathrm{X}=$ skor suatu butir/item

$\mathrm{Y} \quad=$ skor total

Uji validitas dapat diketahui dengan melihat $r$ hitung, apabia $r$ hitung $>r$ tabel maka instrumen atau item pertanyaan berkorelasi signifikan terhadap skor total (dinyatakan valid). Apabila $r$ hitung $<r$ tabel, maka instrumen atau item pertanyaan tidak berkorelasi signifikan terhadap skor total (dinyatakan tidak valid). Uji Reliabilitas, menurut Misbahuddin dan Hasan (2013:17) bahwa suatu alat ukur dikatakan memiliki reliabilitas apabila digunakan berkali-kali oleh peneliti yang sama atau oleh peneliti lain akan memberikan hasil yang sama. Adapun rumus koefisiean reliabilitas Alpha Cronbach sebagai berikut:

$r_{11}=\longdiv { \frac { k } { k - 1 } ] [ 1 - \frac { \sum \sigma _ { b } ^ { 2 } } { V _ { t } ^ { 2 } } ] }$

Di mana $r_{11} \quad=$ reliabilitas instrumen

$\mathrm{k}=$ banyaknya butir pertanyaan atau banyaka soal

$\sum \sigma_{b}^{2} \quad$ jumlah varian butir/item

$V_{t}^{2} \quad=$ varian total

Kriteria suatu instrumen penelitian variabel dikatakan reliabel apabila koefisien reliabilitas $>0,6$ atau dengan dibandingkan dengan $\mathrm{r}$ tabel (Product Moment). Jika nilai koefisien reliabilitas Alpha Cronbach lebih besar dari $\mathrm{r}$ tabel, maka dikatakan reliabel dan sebaliknya. Uji normalitas data, menurut Getut Pramesti (2017:5) bahwa uji normalitas dilakukan untuk mengetahui apakah sampel yang digunakan mengikuti asumsi distribusi normal. Uji normalitas ini dilakukan dengan menggunakan uji Kolmogorov-Smirnov. Adapun hipotesis dalam uji normalitas data yang digunakan adalah sebagai berikut:

$\mathrm{H}_{0}$ : residual tersebar normal

$\mathrm{H}_{1}$ : residual tidak tersebar normal

Jika nilai sig. ( $p$-value $)>0,05$, maka $\mathrm{H}_{0}$ diterima yang artinya normalitas terpenuhi.

Uji Signifikansi (Uji t), menurut Damodar Gujarati (2004:129) menjelaskan bahwa uji signifikansi dikembangkan bersama garis independen oleh R. A. Fisher serta oleh Neyman dan Pearson. Secara garis besar, uji signifikansi adalah prosedur dimana hasil sampel digunakan untuk memverifikasi kebenaran atau kesalahan sebuah hipotesis nol. Adapun uji signifikansi dilakukan dengan cara menghitung nilai $t$ dengan rumus sebagai berikut: 
$\mathrm{t}=\mid \frac{\widehat{\beta_{2}}}{\operatorname{se} \widehat{\beta_{3}}}$,

Keterangan:

$\overline{\beta_{2}}=$ nilai koefisien regresi $\mathrm{X}$

se $\hat{\beta}_{2}=$ standar eror

Jika nilai t hitung $\geq \mathrm{t}$ tabel maka $H_{0}$ ditolak dan $H_{1}$ diterima, yang artinya terdapat pengaruh yang signifikan antara spiritualitas (spiritualitas) dan persepsi dukungan organisasi (perceived organizational support) terhadap keterikatan kerja (employee engagement) anggota Satuan Reserse Polres Lamongan. Sedangkan apabila thitung $<\mathrm{t}$ tabel maka $H_{0}$ diterima dan $H_{1}$ ditolak, yang artinya bahwa tidak terdapat pengaruh yang signifikan antara spiritualitas (spiritualitas) dan persepsi dukungan organisasi (perceived organizational support) terhadap keterikatan kerja (employee engagement) anggota Satuan Reserse Polres Lamongan. Dalam penelitian ini peneliti menggunakan program SPSS 24 untuk melakukan uji signifikansi tersebut.

Uji statistik F pada dasarnya menunjukkan apakah semua variabel independen atau bebas dalam model berpengaruh secara simultan atau bersama-sama terhadap variabel dependen (Ghozali 2013). Dalam penelitian ini desertakan pengujian serentak (uji F) untuk mengetahui apakah variabel bebas yakni variabel spiritualitas (spirituality) dan variabel Persepsi dukungan organisasi (perceived organizational support) secara serentak atau bersama sama berpengaruh terhadap keterikatan kerja (employee engagement). Adapun langkah-langkah dalam uji $\mathrm{F}$ adalah sebagai berikut: $\mathrm{H} 0: \beta 1, \beta 2=0$ variabel spiritualitas (spiritualitas) dan variabel persepsi dukungan organisasi (perceived organizational support) secara serentak atau bersama sama tidak berpengaruh terhadap employee engagement $(\mathrm{Y})$ ). $\mathrm{H} 1: \beta 1, \beta 2 \neq 0$ variabel spiritualitas (spiritualitas) dan variabel persepsi dukungan organisasi (perceived organizational support) secara serentak atau bersama sama berpengaruh terhadap employee engagement (Y). Apabila nilai signifikansi $0,000<0,05$ maka $\mathrm{H} 0$ ditolak dan $\mathrm{H} 1$ diterima dan apabila nilai signifikansi > 0,05 maka $\mathrm{H} 0$ diterima.

Uji dominan digunakan untuk mengetahui variabel yang paling berpengaruh terhadap keterikatan kerja (employee engagement) anggota Satuan Reserse Polres Lamongan. Adapun uji dominan ini dengan menggunakan koefisien beta yang telah terstandardisasi pada uji regresi. Dalam teknik analisis data semua perhitungan tersebut di atas dilakukan dengan menggunakan program SPSS 24. Menurut Damodar Gujarati (2004:174) kita dapat menghitung variabel yang paling berpengaruh dengan menggunakan koefisien beta pada analisis regresi. Adapun rumus untuk mencari koefisien beta adalah sebagai berikut:

$\beta=\hat{\beta}\left(\frac{s_{x}}{s_{y}}\right)$

Di mana $\beta=$ koefisien beta

$\widehat{\beta}=$ koefisien regresi $X$

$S_{x}=$ standar deviasi variabel kualitas pelayanan

$S_{y}=$ standar deviasi variabel kepuasan masyarakat

\section{Hasil dan Pembahasan}

\section{Pengaruh spirituality terhadap employee engagement anggota Satuan Reskrim Polres Lamongan}

Pengaruh spiritualitas terhadap keterikatan kerja (employee engagement) anggota Satuan Reskrim Polres Lamongan secara parsial dapat dilihat dari hasil uji t. Uji t digunakan untuk menjelaskan apakah terdapat pengaruh yang signifikan antara spiritualitas terhadap employee engagement anggota 
Satuan Reskrim Polres lamongan. Jika hasilnya signifikan, maka $\mathrm{H}_{0}$ ditolak dan $\mathrm{H}_{1}$ diterima. Jika hasilnya tidak signifikan, maka $\mathrm{H}_{0}$ diterima dan $\mathrm{H}_{1}$ ditolak. Apabila hasilnya tidak signifikan, maka $\mathrm{H}_{0}$ diterima dan $\mathrm{H}_{1}$ ditolak.

Variabel spiritualitas adalah salah satu faktor yang mengakibatkan keterikatan hati dan pikiran para karyawan terhadap pekerjaan dan tempat kerjanya (Ursitti 2011). Hal tersebut terlihat dari perilaku dan sikap kerja karena hal tersubut potensial dalam meningkatkan derajat keterikatan kerja (employee engagement). Spiritualitas membangkitkan perasaan positif dan keadaan pikiran (state of mind) yang dicirikan dengan semangat (vigor), dedikasi (dedication) dan keasikan (absorption) di tempat kerja (Kirana 2015). Dari penjelasan teori tersebut bahwa spirituality memiliki keterkaitan dengan keterikatan kerja (employee engagement). Berdasarkan hasil uji t diketahui ada pengaruh yang signifikan antara spiritualitas terhadap keterikatan kerja (employee engagement) anggota Satuan Reskrim Polres Lamongan. Hasil uji t menyatakan bahwa t hitung variabel spirituality terhadap variabel keterikatan kerja (employee engagement) anggota Satuan Reskrim Polres Lamongan sebesar 2,267 dan nilai signifikansi sebesar 0,027 lebih kecil dari taraf signifikansi 0,05. Arti nilai uji t ini menyatakan bahwa variabel spirituality berpengaruh secara signifikan terhadap keterikatan kerja (employee engagement) anggota Satuan Reskrim Polres Lamongan.

Hal tersebut di atas juga dapat dilihat dari jawaban responden dalam hal ini anggota Satuan Reskrim Polres Lamongan terhadap pertanyaan terbuka yang diajukan oleh peneliti. Pada pertanyaan pertama yang diajukan kepada responden yakni tentang bagaimana responden mewujudkan pemahaman akan keyakinan adanya kekuatan diri dan bagaimana menggunakan kekuatan itu dalam memberikan makna keberartian terhadap pelaksanaan tugas dan pekerjaan. Responden menjawab bahwa dengan berusaha untuk bekerja dan menyelesaikan pekerjaan dengan baik, serta dengan keyakinan diri bahwa membela orang yang teraniaya maka responden merasa dekat dengan Tuhan. Selain itu responden juga menjawab bahwa tugas pekerjaan merupakan kebutuhan hidup yang harus dilakukan dengan ikhlas dan bernilai ibadah. Responden yang lain menjawab bahwa sebelum melaksanakan pekerjaan maka responden berdoa kepada Tuhan Yamg Maha Esa agar dimudahkan segala urusan dalam pekerjaan sehingga hal tersebut merupakan kekuatan dan kepercayaan diri responden karena meyakini bahwa Tuhan bersama responden.

Disamping itu responden juga menjawab bahwa dalam melaksanakan tugas dan pekerjaan, responden menjunjung tinggi integritas dan kejujuran, bekerja sesuai aturan dan prosedur mengingat semua akan dipertanggungjawabkan di hadapan Tuhan Yang Maha Esa kelak. Hal tersebut sesuai dengan dimensi innerness atau inner resources Ursitti (2011) mendefinisikan innernes sebagai perjuangan atau pencarian akan keutuhan, identitas dan rasa pemberdayaan diri. Hal tersebut dimanifestasikan dalam perasaan penguatan dalam kondisi tertekan atau krisis. Dapat juga beruwujud rasa tenang dalam menghadapi situasi ketidakpastian serta teori yang disampaikan Ursitti (2011), inner resources memberikan pemahaman kepada individu akan keyakinan adanya kekuatan diri dan bagaimana menggunakan kekuatan itu untuk memenuhi kepuasan dan kepercayaan diri yang diterjemahkan dalam memberikan makna keberaratian dalam melakukan pekerjaannya dalam lingkungan kerja.

Jawaban responden terhadap pertanyaan terbuka kedua yang diajukan oleh peneliti tentang bagaimana responden membuat pekerjaan yang responden lakukan berarti bagi kehidupan responden yaitu bahwa responden selalu merasa bersyukur kehadirat Tuhan Yang Maha Esa terhadap tugas yang diembannya. Jawaban lain adalah responden bekerja sesuai dengan tugas pokoknya sebagai anggota Satuan Reskrim Polres Lamongan dan berusaha tidak menyimpang serta selalu berusaha bekerja dengan sebaik-baiknya dengan rasa ikhlas dan tanggung jawab. Responden juga menjawab bahwa apa yang dialami korban mendorong responden untuk menolong mereka dan responden meyakini bahwa dengan menolong korban atau masyarakat maka akan berbalas pahala dari Tuhan Yang Maha Esa serta memberikan arti dan tujuan hidup responden dalam melaksanakan pekerjaannya. Jawaban tersebut merupakan bagian dari dimensi purpose and meaning in life, yakni individu memiliki perasaan yang sama dalam mencari maksud dan makna yang lebih mendalam dalam kehidupannya dan juga terhadap pekerjaan yang dilakukannya. Rasa tujuan (sense of purpose) atas apa yang dikerjakan dapat muncul 
dari kualitas intrinsik dari pekerjaan yang sedang dilakukannya, maupun tujuan yang akan dicapai atau dicari dari suatu pekerjaan.

Jawaban responden terhadap pertanyaan nomor tiga yang diajukan peneliti yakni tentang tindakan yang dilakukan responden ketika responden berada dalam situasi tertekan atau terdesak adalah bahwa responden berdoa kepada tuhan Yang Maha Esa agar diberikan kemudahan dan jalan keluar dalam situasi tersebut. Selain itu jawaban responden yang lain yakni bahwa responden berusaha menguasai diri dan menenangkan diri serta istighfar dan mempelajari situasi tersebut untuk menemukan solusi. Selain itu responden juga menjawab dengan meminta perlindungan kepada Tuhan Yang Maha Esa apabila dalam situasi yang terdesak. Transendensi didapat dari individu yang terlibat dalam pekerjaan yang dapat memberikan makna, kejadian yang memunculkan rasa kasih, atau dari perilaku yang dapat membuat seseorang bertahan dari penderitaan yang tak terhindarkan (Ursitti 2011). Pengalaman dan proses yang dilalui tersebut dapat menimbulkan pergeseran dari egoisme yang mementingkan diri sendiri ke rasa kepedulian terhadap sesama dan menimbulkan kesadaran akan adanya kekuatan Tuhan atau kekuatan yang lebih besar di luar dirinya sesuai dengan apa yang menjadi jawaban responden dalam hal ini anggota Satuan Reskrim Polres Lamongan.

Pada pertanyaan terbuka nomor empat yakni tentang apa yang responden rasakan ketika responden terlibat dalam suatu pekerjaan penting dan terhubung dalam komunitas pekerjaan responden, responden sebagian besar menjawab bahwa responden merasa bangga dan berusaha melaksanakan pekerjaan tersebut dengan sebaik-baiknya dan penuh tanggung jawab. Responden yang lain menjawab bahwa responden merasa berguna bagi organisasi dan komunitasnya. Selain itu responden merasa senang karena menjadi bagian penting bagi komunitas dan organisasinya. Responden yang lain menjawab bahwa tergabung dalam pekerjaan dan komunitas saat ini merupakan suatu kehormaatan bagi responden karena tidak semua orang bisa terlibat dan menjadi pembelajaran serta pengalaman yang berharga bagi responden. Jawaban responden tersebut merupakan dimensi unifying interconnectedness, tempat kerja adalah sebuah komunitas. Perasaan menjadi bagian dari suatu komunitas adalah elemen yang esensial dari perkembangan spiritualitas individu (Ursitti 2011). Memahami spiritualitas di tempat kerja adalah menyadari bahwa orang memiliki kehidupan di dalam dirinya maupun di luar dirinya. Spiritualitas di tempat kerja muncul diantaranya dikarenakan individu ingin merasa terlibat dalam pekerjaan yang penting dan merasa terhubung dengan orang di lingkungannya satu sama lain. Ketika seseorang bekerja, hubungan dengan orang di sekitarnya merepresentasikan bagian dari kehidupannya sehari-hari (Ursitti 2011).

\section{Pengaruh perceived organizational support terhadap employee engagement anggota Satuan Reskrim Polres Lamongan}

Pengaruh perceived organizational support terhadap keterikatan kerja Employee engagement Anggota Satuan Reskrim Polres Lamongan secara parsial dapat dilihat dari hasil uji t. Berdasarkan hasil uji t diketahui bahwa terdapat pengaruh yang signifikan antara perceived organizational support terhadap keterikatan kerja (employee engagement) anggota Satuan Reskrim Polres Lamongan. Hasil uji t menyatakan bahwa t hitung variabel Perceived Organizational Support terhadap variabel keterikatan kerja (Employee engagement) anggota Satuan Reskrim Polres Lamongan sebesar 15,060 dan nilai signifikansi sebesar 0,000 lebih kecil dari taraf signifikansi 0,05 serta nilai $t$ hitung > $t$ tabel 15,060 > 1,671 maka H0 ditolak dan $\mathrm{H} 1$ diterima. Hal ini menunjukkan bahwa secara parsial variabel perceived organizational support berpengaruh signifikan terhadap keterikatan kerja.

Adapun pertanyaan terbuka yang diajukan oleh peneliti terhadap responden yang pertama adalah tentang bagaimana organisasi dan atasan tempat responden bekerja saat ini menunjukkan kepedulian terhadap kesejahteraan responden. Responden manjwab bahwa organisasi saat ini sangat peduli terhadap kesejahteraan responden yakni salah satunya dengan adanya tunjangan kinerja yang diberikan kepada responden. Responden yang lain menjawab bahwa ada reward yang diberikan oleh atasan kepada responden terhadap keberhasilan tugas dan pekerjaan yang diembannya. Responden juga menjawab bahwa organisasi dan atasan sangat peduli terhadap reponden ketika responden sakit atau ketika responden sedang berada dalam kesulitan, organisasi dirasa hadir menguatkan responden. 
Disamping itu responden juga menerima hak-haknya tepat waktu tanpa ada keterlambatan atau potongan yang dibebankan kepada reponden misalnya pemberian gaji dan tunjangan. Hal tersebut sesuai dengan teori Rhoades \& Eisenberger (2002) yang mendefinisikan persepsi dukungan Organisasi (perceived organizational support) sebagaimana seorang karyawan mempersepsikan organisasinya terkait dengan well being karyawan tersebut atau suatu kontribusi dan kepedulian organisasi terhadap kesejahteraan karyawan. Teori dukungan organisasi mengandaikan bahwa untuk menentukan kesiapan organisasi untuk mengahargai peningkatan upaya kerja, karyawan menegembangkan keyakinan mengenai sejauh mana organisasi menghargai kontribusi mereka dan peduli tentang kesejahteran mereka (Ucar \& Otken 2010; Murthy 2017; Khan \& Chandrakar 2017).

Jawaban responden terhadap pertanyaan terbuka yang diajukan oleh peneliti tentang sejauh mana atasan responden menilai kontribusi responden terhadap organisasi serta melaksanakan evaluasi performa dan kinerja responden. Dalam hal ini responden menjawab bahwa atasan memberikan penilaian terhadap kinerja responden dilihat dari penyelesaian perkara yang menjadi tugas dan tanggung jawab responden. Selain itu responden juga menyampaikan bahwa atasan selalu melaksanakan evaluasi dan penilaian kinerja anggota secara rutin dan berkala serta memberikan reward dan punishment terhadap evaluasi yang sudah dilakukan serta pemberian motivasi jika terdapat penurunan dalam pelaksanaan pekerjaan. Hal ini sesuai dengan dimensi supervisor support, yakni tindakan kebijakan dan keputusan seorang atasan dalam suatu organisasi. Atasan pada organisasi juga mempunyai wewenang untuk mengarahkan dan mengevaluasi performa dan kinerja bawahannya. Karyawan membentuk persepsi secara umum mengenai penilaian organisasi, mereka mengembangkan pandangan umum yang menyangkut sejauh mana supervisor / atasan menilai kontribusi mereka dan peduli tentang kesejahteraan mereka, yaitu terkait dukungan atasan yang dirasakan oleh anggotanya (Rhoades \& Eisenberger 2002).

Jawaban responden terkait dengan pertanyaan terbuka yang diajukan oleh peniliti yakni tentang bagaimana organisasi mengkomunikasikan penilaian positif terhadap kontribusi responden sehingga menimbulkan persepsi bahwa organisasi memberikan perhatian kepada responden yakni bahwa banyak perkara-perkara berat dan sulit yang ditangani responden supaya tidak menjadi gejolak atau permasalahan di masa mendatang maka pekerjaan tersebut dipercayakan kepada responden. Jawaban lainnya yaitu responden dipercaya untuk mengikuti kegiatan-kegiatan di luar organisasi baik formal maupun non formal, seperti kegiatan lomba dan sertifikasi penyidik. Selain itu responden juga diberikan kesempatan untuk memberikan masukan ataupn ide-ide dalam suatu diskusi terhadap pemecahan suatu permasalahan. Rhoades \& Eisenberger (2002) menyampaikan bahwa praktik sumber daya manusia oleh suatu organisasi harus menunjukkan pengakuan terhadap kontribusi karyawan terhadap organisasi.

Jawaban responden selanjutnya terkait dengan pertanyaan terbuka yang diajukan oleh peniliti tentang faktor yang bisa membentuk semangat serta ketahanan mental responden dalam menyelesaikan suatu pekerjaan dan menghadapi kesulitan dalam pekerjaan yaitu perhatian organisasi dan perhatian atasan. Selain itu responden juga menjawab bahwa keluarga, atasan, lingkungan kerja, dan rekan kerja yang solid bisa membentuk semangat serta ketahanan mental responden dalam menyelesaiakan masalah. Semangat dikarakteristikkan dengan tingginya level energi dan ketahanan mental saat bekerja, kemauan untuk memberi upaya lebih dalam bekerja dan ketekunan dalam menghadap kesulitan.

Jawaban responden terkait dengan pertanyaan terbuka yang diajukan oleh peniliti tentang apa yang membuat responden bangga, merasa berarti, serta antusias terhadap pekerjaan responden adalah bahwa responden merasa tugas dan tanggung jawab yang diembannya saat ini memberikan manfaat bagi masyarakat dan responden merasa bahwa kehadirannya masih dibuthkan oleh masyarakat. Jawaban yang lain adalah bahwa responden merasa bangga karena apa yang menjadi tugas dan tanggung jawabnya saat ini belum tentu bisa dilakukan oleh orang lain. Selain itu rekan-rekan yang solid dan saling mendukung baik dalam situasi susah dan senang membuat responden antusias terhadap pekerjaan yang diembannya. 
Responden yang lain menjawab bahwa pekerjaannya saat ini merupakan cita-citanya sejak kecil yakni menjadi penegak hukum yang bermafaat bagi masyarakat. Hal tersebut sesuai dengan teori Schaufeli et al (2001) yaitu dimensi dedikasi yang dikarakteristikkan dengan adanya perasaan berarti, antusiasme, inspirasi, kebanggaan dan tantangan (dedication). Jawaban responden selanjutnya terkait dengan pertanyaan terbuka yang diajukan oleh peniliti tentang apa yang membuat responden sulit melepas diri dari pekerjaannya saat ini diantaranya adalah responden ingin menyenangkan keluarga dan menjadi kebanggaan keluarga dan pekerjaan tersebut merupakan jiwa responden sehingga responden sangat mencintai pekerjaan yang diembannya saat ini. Jawaban yang lain adalah adanya gaji dan tunjangan yang diberikan oleh organisasi dimana responden merasa kahwatir apabila terlepas dari pekerjaannya maka tentu saja gaji dan tunjangan yang diterima akan berbeda dan hal ini akan berpengaruh terhadap perekonomian atau kesejahteraan responden dan keluarganya. Responden yang lain menjawab bahwa dengan pekerjaanya saat ini responden merasa lebih dekat dan bermanfaat bagi masyarakat dan sudah sesuai dengan hati nuraninya. Jawaban responden tersebut merupakan dimensi absorption atau kesenangan dalam menjalani pekerjaan, di mana tanpa terasa waktu berjalan cepat dan individu sulit melepas diri dari pekerjaannya.

\section{Pengaruh spiritualitas dan perceived organizational support terhadap employee engagement anggota Satuan Reskrim Polres Lamongan}

Pengaruh spirituality dan perceived organizational support terhadap keterikatan kerja employee engagement anggota Satuan Reskrim Polres Gresik secara simultan atau bersama-sama dapat dilihat dari hasil uji F. Uji statistik F pada dasarnya menunjukkan apakah semua variabel independen atau bebas dalam model berpengaruh secara simultan atau bersama-sama terhadap variabel dependen (Ghozali 2013). Hasil uji $\mathrm{F}$ menyatakan bahwa $\mathrm{F}$ hitung variabel spiritualitas dan perceived organizational support terhadap variabel keterikatan kerja (employee engagement) anggota Satuan Reskrim Polres Lamongan sebesar 915,074 dan nilai signifikansi sebesar 0,000 lebih kecil dari taraf signifikansi 0,05 . Arti nilai uji $\mathrm{F}$ ini menyatakan bahwa variabel spiritualitas dan perceived organizational support secara simultan berpengaruh signifikan terhadap keterikatan kerja (employee engagement) anggota Satuan Reskrim Polres Lamongan.

Berdasarkan hasil perhitungan uji koefisien determinasi $R$ square $\left(\mathrm{R}^{2}\right)$ adalah nilai koefisien determinasi berganda (Adjusted $R$ Square) adalah 0,969 atau 96,9\% yang berarti nilai ini menunjukkan bahwa sebesar 96,9\% employee engagement (Y) dipengaruhi oleh spirituality dan perceived organizational support sedangkan sisanya 3,1\% dipengaruhi oleh variabel lain diluar penelitian.

\section{Simpulan}

Hasil penelitian pada uji signifikansi (uji t) menunjukkan bahwa t hitung variabel Spirituality terhadap variabel keterikatan kerja (employee engagement) anggota Satuan Reskrim Polres Lamongan sebesar 2,267 dan nilai signifikansi sebesar 0,027 lebih kecil dari taraf signifikansi 0,05. Arti nilai uji t ini menyatakan bahwa variabel Spiritualitas berpengaruh secara signifikan terhadap keterikatan kerja (employee engagement) anggota Satuan Reskrim Polres Lamongan. Sedangkan hasil uji t hitung variabel perceived organizational support terhadap variabel keterikatan kerja (employee engagement) anggota Satuan Reskrim Polres Lamongan sebesar 15,060 dan nilai signifikansi sebesar 0,000 lebih kecil dari taraf signifikansi 0,05 serta nilai t hitung > t tabel 15,060 > 1,671 maka H0 ditolak dan H1 diterima. Hal ini menunjukkan bahwa secara parsial variabel perceived organizational support berpengaruh signifikan terhadap keterikatan kerja.

Hasil penelitian pada uji $\mathrm{F}$ sebesar 915,074 dan nilai signifikansi sebesar 0,000 lebih kecil dari taraf signifikansi 0,05. Arti nilai uji F ini menyatakan bahwa variabel Spiritualitas dan Perceived Organizational Support secara simultan (bersama-sama) berpengaruh signifikan terhadap keterikatan kerja (Employee engagement) anggota Satuan Reskrim Polres Lamongan. Nilai koefisien determinasi $R$ square $\left(\mathrm{R}^{2}\right)$ sebesar 0,969 atau $96,9 \%$ yang berarti nilai ini menunjukkan bahwa sebesar $96,9 \%$ Employee engagement $(\mathrm{Y})$ dipengaruhi oleh spirituality dan perceived organizational support sedangkan sisanya $3,1 \%$ dipengaruhi oleh variabel lain di luar penelitian. Variabel perceived 
organizational support (persepsi dukungan organisasi) memiliki pengaruh yang lebih besar daripada variabel spirituality (spiritualitas) terhadap employee engagement (keterikatan kerja), hal ini dapat dilihat dari nilai koefisien beta pada uji dominan (uji t) yakni nilai koefisien beta variabel perceived organizational support (persepsi dukungan organisasi) sebesar 0,864 lebih besar dari nilai koefisien beta variabel spirituality (spiritualitas) sebesar 0,130.

\section{Daftar Pustaka}

Bungin B (2011) Metodologi Penelitian Kuantitatif. Kencan Prenadamedia Group: Jakarta.

Ghozali I (2016) Aplikasi Analisis Multivariete Dengan Program IBM SPSS 23. Semarang: Badan Penerbit Universitas Diponegoro.

Khan Z \& Chandrakar S (2017) Perceived organizational support and personality dimensions as predictors of job satisfaction. Indian Journal of Health and Wellbeing 8 (1):54-46.

Kirana E (2015) Hubungan Antara Dimensi Workplace Spiritualitas dan Employee Engagement, Skripsi. Universitas Sanata Dharma,Yogyakarta.

Lazar A (2009) Spiritualitas and job satisfaction among female Jewish Israeli Hospital nurses. Journal of Advanced Nursing 66 (2):334-344.

Morales PE (2015) An Impirical Study on the Significance of Religiosity and Spiritualitas for Job Satisfaction in Public Service. Dissertation. University of Baltimore, Maryland, USA.

Morash M, Jeong SJ, Haarr RN, \& Hoffman V (2011) The connection of police strategies for coping with workplace problems to stress in two countries. International Journal of Comparative and Applied Criminal Justice 35 (2):89 - 103.

Murthy RK (2017) Perceived organizational support and work engagement. International Journal of Applied Research 3 (5):738 -740.

Rhoades L \& Eisenberger R (2002) Perceived organizational support: A review of literature. Journal of Applied Psychology 87 (4):6998-714.

Schaufeli, Wilamar B, Salanova \& Marisa (2001) The measurement of engagement and burnout: A two sample confirmatory factor analytic approach. Journal of Happiness 3:71-92.

Schaufeli WB (2013) What is Engagement? Employee Egagement in Theory and Practice. London: Routledge.

Srivastava S, Caprihan S, Nigham RM, \& Khemani A (2014) Employee spiritualitas and job engagement: a correlational study acros organizational hierarchy. International Journal of Human Reseach and Development 4(1): $70-88$.

Sugiyono (2014) Metode Penelitian Kuantitatif Kualitatif dan R \& D. Bandung: Alfabeta.

Tucker JM (2015) Police officer willingness to use stress intervention service: The Role of perceived organizational support (POS), confidentiality and stigma. International Journal of Emergency Mental Health and Human Resilence 17 (1):304-314.

Ucar D \& Otken AB (2010) Perceived organizational support and organizational commitment: The mediating role of organization based self-esteem. Dokuz Eylül Üniversitesi İktisadi ve İdari Bilimler Fakültesi Dergisi 25 (2):85-105.

Ursitti AM (2011) A Quantitative Assessment of Spiritualitas in Police Officers and the Relationship to Police Stress, Desertasi. School of Graduate and Continuing Studies, Olivet Nazarene Universit, USA.

Vivek S \& Amrith V (2017) Spiritualitas and productivity - A retionship perspective. Purusharta School of Management Sciences 10 (1):60 - 69.

Zobal C (2014) Employee Engagement: The Impact of Spiritual, Mental, Emotional and Physical Elements on Relationship Between Employee Engagement and Behavioral Outcomes. Dissertation. University of North Texas, USA. 